\title{
A review of the genus Epitrichius Tagawa, with an analysis of the internal sac armature of the male genitalia (Coleoptera: Scarabaeidae: Cetoniinae)
}

\author{
CHUN-LIN LI ${ }^{1}$, PING-SHIH YANG ${ }^{1}$, KUO-SHENG HSU ${ }^{2}$ and CHUAN-CHAN WANG ${ }^{3,4}$ \\ ${ }^{l}$ Department of Entomology, National Taiwan University, Taipei 107, TAIWAN (R. O. C.) \\ ${ }^{2}$ Department of Plant Protection, National Pingtung University of Science and Technology, Neipu, Pingtung 912, TAIWAN (R. O. C.) \\ ${ }^{3}$ Research Center for Biodiversity, Academia Sinica, Taipei 115, TAIWAN (R. O. C.) \\ ${ }^{4}$ Corresponding author
}

\begin{abstract}
This paper redefines the Oriental genus Epitrichius Tagawa (Coleoptera: Scarabaeidae: Cetoniinae: Trichiini) and gives descriptions and illustrations of Epitrichius shinshuingensis, a new species from Taiwan. The genus also includes other six species: E. bowringii (Thomson) new combination, E. cupreipes (Bourgoin) new combination, E. elegans (Kano), E. fraterculus (Moser) new combination \& new status, E. lagopus (Fairmaire), and E. versutus (Krikken) new combination. The following species names are placed in synonymy with E. bowringii: Trichius bifasciatus (Moser) new synonym and T. miyashitai (Krajcik) new synonym. In addition, E. fraterculus duporti (Bourgoin) is placed in synonymy with E. fraterculus. Information on the specimen examination, distribution and known biology of all species is provided. A key to the species of the genus is included. The sclerotized armatures of the internal sac of the male genitalia of Epitrichius was examined and found to provide strong support to separate this genus from other Trichiini genera. This set of characters was also found to be reliable in identifying species in groups with variable parameres.
\end{abstract}

Key words: Epitrichius, Trichiini, new species, checklist, internal sac armature

\section{Introduction}

Tagawa (1941) proposed the genus Epitrichius for two trichiine beetles of Taiwan, E. elegans and E. bifasciatus (the latter species is not known to occur in Taiwan and may have been mislabeled or misidentified). These two species were previously placed in the genus Trichius Fabricius. The diagnostic characteristics proposed by Tagawa to separate Epitrichius from both Trichius and Gnorimus LePeletier \& Audinet-Serville were the combination of body shape, markings on the elytra, the pygidial tubercles in females and the outer teeth of the foretibiae in males. However, the establishment of this new genus has gone virtually unnoticed for almost half a century.

The species that are proposed herein to be included in the genus Epitrichius correspond with Krikken (1972) who first treated those species as members of the T. bifasciatus species group of the genus Trichius. Moreover, Krikken (1984) stated that Trichius was the appropriate generic name for the taxa previously placed in Lasiotrichius Reitter and Paratrichius Janson in eastern and southeastern Asia and for the North American genus Trichiotinus Casey. Apparently, the genus Epitrichius was not known to Krikken and he assigned almost all described Palaearctic species into the genus Trichius, with the exception of those species in the genus Gnorimus. Epitrichius has not been mentioned in the literature since its generic establishment in 1941 until the Isida \& Fujioka (1988) catalog. Here we have followed Tagawa's original concept and modified the generic limits by comparing the type species of Trichius, T. fasciatus, and its relatives in order to broadly 
separate and distinguish Epitrichius from Trichius. The morphological characters that we found in the male genitalia and its value in the use of clarifying the systematic status of genus and species are particularly emphasized.

In this paper, the genus Epitrichius consists of seven species, including a new species that is described here. Species of Epitrichius occur from 50 to 2,000 m in elevation and are geographically restricted to northern Indo-China, eastern China, Taiwan and the Japanese island Amami-Oshima of the Ryukyu archipelago. A synopsis of the genus is provided.

\section{Synopsis of the "Trichius bifasciatus subgroup"}

According to literature concerned, the dorsal color form of the body and the shape of parameres of the male genitalia were the two of the most important morphological characters used to separate the species within the "Trichius bifasciatus subgroup" (sensu Krikken 1972). In this "subgroup," four available names were proposed: T. bowringii (eastern and southern China), T. bifasciatus (northern Vietnam), T. miyashitai (Hainan Island) and T. cupreipes (Taiwan). The dorsal color of $T$. bowringii was distinguished by its overall green coloration and T. bifasciatus by its black elytra. However, with a total of 52 male specimens (for details see the section of specimens examined of E. bowringii below) dissected for the examination of the male genitalia, we found a wide range of continuous variation in the shape of the parameres among specimens formerly recognized as three separate species in this group. Figures 8-12 show the type of variation in male T. bifasciatus (synonymized with E. bowringii herein) collected in a single locality of northern Vietnam. Furthermore, this same range in the shape of the parameres also appears in T. bowringii and T. miyashitai. This phenomenon is probably a reflection of the fact that the shape and variation of the parameres of these species was never scrutinized, likely due to inadequate numbers of specimens being dissected. This oversight regarding the variation in the shape of the parameres is also apparently correlated with the fact that the external features between the typical black elytra (previously treated as T. bifasciatus) (Fig. 13) and overall green (as T. bowringii) (Fig. 16) are easily recognized making dissection unnecessary. In addition, the species delimitation of females for both T. bifasciatus and T. bowringii has traditionally been based on the dorsal color form.

Conventionally, $T$. bowringii has been known to occur from the east to the south east of China, while $T$. bifasciatus has been known to occur in northern Vietnam (Krikken 1972). Nevertheless, there was a black form of the female found in both T. bowringii and T. bifasciatus, which made species distinction difficult using only females. Consequently, the distribution remains the only way to separate these species. Additionally, we obtained a series of specimens from the southern border of China near Vietnam demonstrating variation in the color form of the body including overall green, black elytra and an intermediate form (the dull green elytra, Figs. 14-15) This indicates a potential parapatric area for both species. These findings, including the intermediate form and the continuous variation of the parameres, challenge the existing species concepts within this group using only the shape of parameres and the dorsal body color. Therefore we here propose a new taxonomic arrangement for the species within this group based on a more detailed analysis of the genital characters.

The form of the male genitalia has been widely considered as an important feature to diagnose species for the majority of insects (Eberhard 1985). However, as mentioned above in the case of T. bifasciatus from Vietnam, it is not feasible to treat each type of parameres observed from a single locality as belonging to a different species. On the other hand, we did find that the internal sac armature in the Epitrichius species, namely major and minor hooks, exhibited a particularly stable intraspecific trait other than parameres. The characteristics of the internal sac are often ignored since the parameres are distinct (Skelley 1993). D'Hotman \& Scholtz (1990a) considered that the internal sac armature is usually highly species-specific in the Scarabaeoidea. In practice, however, there are only few limited examples using the internal sac to diagnose species, 
unless the taxa share similar parameres (e.g. Chandra 1991). In Trichiini males, very few species were known to bear internal sac armature. D'Hotman \& Scholtz (1990b) mentioned that they observed an undetermined Trichius species that had an armed internal sac. Howden (1994) was probably the first author to use the sclerotized armature on the internal sac for species-level diagnosis in Trichiini. He used them to separate two similar Apeltastes Howden trichiine species from Mexico. In most of the trichiine cases we examined or that were referred to by D'Hotman \& Scholtz (1990a, 1990b), the internal sac appeared to be armed only with unnoticeable, tiny spines, and/or rarely with sclerotized plates connected to temones. The differences in the shape and size of the internal sac structures may play different roles during copulation with females. D'Hotman \& Scholtz (1990a, 1990b) mentioned that the structures serve to intromit and fix the female or perform a sensory function during copulation. Recent research on beetles revealed that these interesting structures may be a result of multiple evolutionary processes such as sexual selection (e.g. sperm competition; Haubruge 1999, House \& Simmons 2003) and sexual conflict (Crudgington \& Siva-Jothy 2000).

D'Hotman \& Scholtz (1990b) observed a high degree of similarity in the male genitalia of trichiines. We have found that this morphological trend in Epitrichius species, but the interesting phenomenon of the differences in internal sac armature in this genus bear further investigation in both an evolutionary and comparative biology context. Figures 17 and 18 illustrate the shape of the major hooks of the internal sac of E. bowringii and $E$. cupreipes, respectively. The number of denticles of the dorsal ridge varies among individuals of each species. The lateral denticle of E. cupreipes is always present and noticeable whereas in E. bowringii it is completely absent or vestigial.

Considering the potential interbreeding of populations and the intermediate form observed in the contact zone in southern China, as well as the highly consistent species-specific characteristics of the internal sac armature, we hereafter conclude that both T. bifasciatus and T. miyashitai meet the range of intraspecific and geographic variation of E. bowringii and should be placed in synonym with E. bowringii. A similar case is also seen with Trichius fraterculus duporti Bourgoin, which should be conspecific with Epitrichius fraterculus (Moser).

\section{Materials and methods}

With the exception of materials collected by the authors, most specimens examined in this study were borrowed and deposited from the following institutions and private collections (the names of the curators are given in parentheses): BMNH, The Natural History Museum, London (Max Barclay); CCLI, Collections of Chun-lin Li; ISNB, Institut Royal des Sciences Naturelles de Belgique, Brusseles, Belgium (Alain Drumont); NSMT, National Science Museum, Tokyo, Japan (Shûhei Nomura); RMNH, Nationaal Natuurhistorisch Museum, Leiden, The Netherlands (Jan van Tol); TARI, Taiwan Agriculture Research Institute, Taichung, Taiwan (Hsien-tzung Shih); ZMHB, Museum für Naturkunde of the Humbold-University in Berlin (Manfred Uhlig); ZMUC, Zoological Museum, University of Copenhagen, Denmark (Alexey Solodovnikov).

A measurement was made of the largest and smallest individuals of each species with the body length measured from the apex of the clypeus to the apex of the elytra. Each male specimen was dissected and the genitalia was removed in a hot water solution of $10 \% \mathrm{KOH}$ for further clearance and disarticulation. An attempt was then made to evert the internal sac from the tubus with forceps. The relaxation, inflation and observation of the internal sac were done in glycerin under a microscope after it was washed in $95 \%$ ethanol. All parts of the aedeagus were glued to a point of paper or stored in a microvial (particularly those of internal sac) with glycerin that was pinned with the specimens. The male genitalic terms used in this paper are generally those used by D’Hotman \& Scholtz (1990a, b) 


\section{Genus Epitrichius Tagawa, 1941}

Epitrichius Tagawa, 1941: 18; Isida and Fujioka 1988: 58 (catalog); Fujioka 2001: 127 (catalog, comment). Type species: Trichius elegans Kano, 1931 by original designation.

As it is currently defined, Epitrichius includes a morphologically diverse group of species. Epitrichius can be diagnosed by the lack of cretaceous markings over the body surface, the ventral side of the metatarsomeres has a conspicuous fringe of long setae in the males and the internal sac of the male genitalia has two distinct, hook-like armatures. The paired tufts of long setae on the pygidium (usually more developed in the females than the males) is also a feature of this genus.

Some other characteristics show different degrees of variation among the species. The dorsal surface may be dully velutinous or glabrous with a shiny metallic luster. The anterior margin of the clypeus may be smooth to strongly emarginate medially. Both the head and the pronotum are moderately punctate to rugopunctate and setose. The general shape of the pronotum varies from elongate to rounded with outwardly acute basolateral angles. The elytral markings are always well defined with two or three transverse bands, or they are fragmented into spots, except in the males of E. shinshuingensis where markings are diffused marginally. The mesometasternal process is usually vestigial but is distinctly protruding in E. shinshuingensis. The interparamere extension plate varies in the degree of sclerotization from well-developed to semi-membranous.

The species of Epitrichius are distinctly sexual dimorphism compared to some other genera within the tribe Trichiini. The shape of the protibia makes it possible to distinguish the sex in all species in the genus as a unidentate protibia indicates males and a bidentate protibia indicates females. The fringe of setae at the ventral side of the metatarsomeres is found only in males, and the females have distinctly shorter and sparser setae. In males the shape of the pygidium is convex apically and is slightly elongated, while it is truncated in females. Tubercles on the pygidium occur on only females of E. cupreipes, E. bowringii and E. elegans, all of which exhibit a pair of longitudinally ridged or papillose tubercles at the apical half of the pygidium.

Remarks. Krikken (1972) divided his Trichius bifasciatus species group into three "subgroups:" T. elegans, T. bifasciatus and T. fraterculus. However, we reject the concept of delimiting groups and subgroups before a comprehensive phylogenetic analysis is conducted for the genus Epitrichius. The most important characteristics used to separate the species are the anterior margin of the clypeus, the basolateral angles of the pronotum, the pattern of the elytral markings, the development of the setae on the pygidium, the degree of sclerotization of the inter-paramere extension plate and the shape of the parameres and internal sac armature of the male genitalia.

\section{Key to species of the genus Epitrichius Tagawa}

1 Anterior margin of clypeus distinctly raised, moderately to slightly emarginated medially, bilobed tips rounded

1' Anterior margin of clypeus not raised, distinctly emarginated medially, bilobed tips protruding ...............4

2 Dorsum usually overall shiny metallic green in males, metallic green or cupreous in females, females rarely blackish brown without metallic luster; basolateral angles of pronotum protruding basally; pygidium with a pair of median tufts of setae in both sexes. Taiwan Epitrichius elegans (Kano, 1931)

2' Head and pronotum dull green, cupreous or black; basolateral angles of pronotum rounded, retracted; pygidium lacking a pair of median tufts of setae, setiferous overall with a small glabrous area centrally in males

3 Head, pronotum (partly with copper red in females) and scutellum overall dull green with dense, short setae and distinct rugosity of surface, lacking lateral setose spot on sides of pronotum; major hook of internal sac always with lateral denticle (Fig. 18). Taiwan... Epitrichius cupreipes (Bourgoin, 1915) 
3' Overall green in males and dark in females, males collected from northern Indochina and southernmost China usually with elytra black or dull green; head and pronotum with or without velutinous surface; head glabrous, central disc of pronotum sparsely setiferous or nearly glabrous with distinctly marginal setae, setose spot on sides of pronotum present; lateral denticle of major hook of internal sac absent or vestigial (Fig. 17). Eastern and southern China, northern Vietnam, northeastern Laos

4 Pronotum distinctly setiferous; mesometasternal process not visible when viewed laterally........................5

4' Pronotum glabrous or marginally setose; mesometasternal process visible when viewed laterally..............6

5 Head, pronotum and scutellum with iridescent luster; basolateral angle of pronotum distinctly produced; elytron with triple transverse markings; pygidium transversally setiferous with paired tufts vaguely defined in both sexes. Amami-Oshima Island, southwestern Japan. Epitrichius lagopus (Fairmaire, 1897)

5' Head, pronotum, scutellum and legs with copper red or green metallic luster; basolateral angle of pronotum weakly produced; elytron with double transverse markings; pygidium with paramedian paired tufts consisted of well defined long setae in both sexes. Northern Vietnam....Epitrichius versutus (Krikken, 1972)

6 Elytra reddish brown with transverse markings diffused marginally and weakly defined; internal side of metatarsomeres 1-2 densely covered with long, yellowish brown, setae

Epitrichius shinshuingensis Li \& Yang, n. sp.

6' Elytra black with transverse markings not diffused marginally and well defined; internal side of metatarsomeres 1-2 sparsely covered with short, whitish yellow setae. Epitrichius fraterculus (Moser, 1902)

\section{Checklist of the genus Epitrichius Tagawa}

1. Epitrichius bowringii (Thomson, 1857), new combination

Trichius mandarinus Redtenbacher, 1867

Trichius bifasciatus Moser, 1902, new synonym

Trichius miyashitai Krajcik, 2006, new synonym

2. Epitrichius cupreipes (Bourgoin, 1915), new combination

Gnorimus formosanus Niijima \& Kinoshita, 1923

Trichius uraiensis Kano, 1931

3. Epitrichius elegans (Kano, 1931)

Trichius taiheisanus Kano, 1931

4. Epitrichius fraterculus (Moser, 1902), new combination \& new status

Trichius duporti Bourgoin, 1913, new synonym

5. Epitrichius lagopus (Fairmaire, 1897)

Trichius ferriei Pouillaude, 1913

6. Epitrichius shinshuingensis Li \& Yang, new species

7. Epitrichius versutus (Krikken, 1972), new combination

\section{Epitrichius elegans (Kano, 1931)}

Trichius elegans Kano, 1931: 127 (Type locality: Taiheizan, Taiwan. Holotype in NSMT); Miwa \& Chûjô $1939: 30$ (catalog); Krikken 1972: 485, 492 (key, diagnosis).

Trichius taiheisanus Kano, 1931: 128; Smetana 2006: 308 (junior synonym).

Epitrichius elegans: Tagawa 1941: 21 (generic combination); Smetana 2006: 308 (catalog).

Trichius elegans var. taiheisanus: Krikken 1972: 486 (new status). 
Type material examined. The male holotype, deposited in NSMT, is pinned with the following label: Taiheizan, 8.VI-1926 / HOLOTYPE, Trichius elegans KANO, 1931.

Other specimens examined. TAIWAN. Ilan: Taiheizan, 8.VI-1926 (1 female, holotype of Trichius taiheisanus Kano, 1931, NSMT); 100 Logging Road, 17-VI-13-VII-2005, C. L. Li (4 males, 1 female, CCLI) (by flight intercept trap, FIT). Taoyuan: Mt. Lalashan, 5-VI-1990, C.-L. Li (1 female, CCLI). Kaoi, 14-VI-1987, C.-L. Li (1 male, CCLI); Balin, 5-VII-1996, C.- L. Li (1 female, CCLI). Hsinchu: Ximakuxi, 11-VI-2002, C. L. Li (1 male, 1 female, CCLI); Nantou: Peishankeng, 20-V-1941 (1 female, NSMT); ibid, 27-VI-1935 (1 female, NSMT); Chiayi: Jujiro, 2-VIII-1968, K. Yamamoto (1 female, NSMT); Kaohsiung: Meilan Logging Road, 4-VII-1998, C. L. Li (2 females, CCLI); Pingtung: Dahaim Logging Road, 1-IX-2004, C. L. Li (3 females, CCLI); Hwalien: Wanjung Logging Road, 2-VII-1998, C. L. Li (1 male, 2 females, CCLI); Tzeen, 29-VI--1996, C. L. Li (2 males, 1 females, CCLI).

Distribution. Taiwan (Fig. 19).

Remarks. Ma (1995) reported that Epitrichius elegans is distributed in the Chinese insular province Hainan, southern China. However, we did not find any other specimens and/or collecting records of the species in Hainan. Because E. elegans is a splendid trichiine that can be easily distinguished from other species in the genus, we therefore treat the record from the island Hainan as doubtful. Adults of E. elegans are widely distributed throughout the Central Mountain Ranges of Taiwan and the adjacent mountains ranging from 600$2000 \mathrm{~m}$ in elevation. The temporal distribution of T. elegans ranges from the end of May to early September with most found visiting flowers in the forest canopy.

\section{Epitrichius cupreipes (Bourgoin), new combination}

Trichius cupreipes Bourgoin, 1915: 175 (Type locality: Formose, presently Taiwan. lectotype in BMNH); Miwa 1931: 276 (catalog); Miwa \& Chûjô 1939: 30 (catalog); Krikken 1972: 488 (lectotype designated, key, diagnosis); Smetana 2006: 310 (catalog).

Gnorimus formosanus Niijima \& Kinoshita, 1923: 236; Krikken 1972: 488 (synonymized with Trichius cupreipes).

Trichius uraiensis Kano, 1931: 130; Krikken 1972: 488 (synonymized with Trichius cupreipes).

Specimens examined. TAIWAN. Taipei: Wulai, 9-V-1928 (1 male, holotype of Trichius uraiensis Kano, 1931, NSMT); Mt. Tsaoshan (presently Yangmingshan), 21-IV-1958, K. S. Lin (15 males, 24 females, TARI); Mt. Yangming, 9-V-1970, Y. Kiyoyama (4 females, NSMT); Mt. Kwaishan, 11-VI-1988, Y.-F. Hsu (1 female, CCLI); ibid, 1-VII-1935 (1 female, NSMT); Shengken, 11-V-1983, C. L. Li (1 female, CCLI); Tauyuan: Balin, 6-VIII-1997, C.-L. Li (1 male, CCLI); Kaoi, 14-VI-1987, C.-L. Li (1 male, CCLI); Balin, 5-VII-1996, C.-L. Li (1 female, CCLI); Hsuanyuan, 20-VI-1938 (1 male, NSMT); ibid, 27-VI-1940 (2 males, NSMT); Nantou: Peishankeng, 16-V-1939 (1 female, NSMT); ibid, 3-IV-1941 (1 male, 3 females, NSMT); Bandai, $27-$ VI-1938 (1 male, NSMT); ibid, 25-V-1940 (1 female, NSMT); Ilan: Shenmi Lake, 9 June 1993, I.-S. Hsu (2 males, CCLI).

Distribution. Taiwan (Fig. 19).

Remarks. The species can be recognized by the dull green head, pronotum (partly with copper red in females) and scutellum; the dense rugosity on the pronotum and scutellum; the absence of a lateral setose spot on the disc of the pronotum. Also, the major hook of the internal sac is always with a lateral denticle (Fig. 18) thereby distinguishing E. cupreipes from all allied species from mainland China and Indochina. Adults are active from March to August in the low elevation montane areas of Taiwan below $1500 \mathrm{~m}$ in elevation (mostly under $1000 \mathrm{~m}$ ) and feed on the flowers of trees, shrubs or herbs without any specific preference. 
Trichius bowringii Thomson, 1857: 118 (Type locality: Shanghai, China); Miwa 1931: 276 (catalog); Miwa \& Chûjô 1939: 30 (catalog); Smetana 2006: 310 (catalog).

Trichius bowringi: Krikken 1972: 487 (key, diagnosis).

Trichius mandarinus Redtenbacher, 1867: 82 (synonymized by Krikken 1972).

Trichius bifasciatus Moser, 1902: 532 (Type locality: Montes Mauson, North Vietnam. Syntype in ZMHB). New synonym.

Trichius miyashitai Krajcik, 2006: 25 (Type locality: Mt. Wu-Zhi-Shan, Hainan island, China. Holotype, allotype and paratype in Milan Krajcik's private collection, Czech Republic). New synonym.

Specimens examined. CHINA. Shang Hai (without further data) (1 male, coll. E. Candèze, ISNB); Pékin (without further data) (1 male, ISNB); N. Kina (without further data) (1 male, coll. Mus. Westerm, ZMUC); Chekiang (without further data) (1 female, ZMUC); China (without further data) (1 female, ZMUC); China (without further data) (1 female, coll. Mus. Western, ZMUC); Pekin (without further data) (1 female, ISNB); Jiangxi: Jing Gang Shan, 2-14-VI-1994, E. Jendek \& O. Šauša (2 males, 1 female, CCLI); Zhijian: Lin An, Long Ton Shan, ca. 900-1200m., 18-19-VII-1997, Y. F. Hsu (1 female, CCLI); Guangdong: Nan Ling, ca. 900-1000m., 14-16-VI-1999, Y. F. Hsu (1 female, CCLI); Gwongxi: Kin Shiu, Gong Cheng San Jiang, VI2001 (5 males, 2 females, CCLI); Kin Shiu, Mt. Da Yau Shan, ca. 800-1200m., V-VI-1996 ( 7 males, 10 females, CCLI); Hainan: Mt. Wu Zhi Shan, 6-V-2005, T. Miyashita (1 male, 1 female, CCLI); Lan Shan, VII2005 (1 male, CCLI); Mt. Diauh Lo, 1200m., 2-5-V-2005, T. Miyashita (11 males, 1 female, CCLI). VIETNAM. Tonkin, Montes Manson (presently Mauson Mountains, northern Vietnam), April, Mai, 2-3000', H. Fruhstorfer (23, ZMUC); Tonkin, Than-Moi, Juni-Juli, H. Fruhstorfer (1, ZMUC); Vin Phu: Tam Dao, V-1994 (1 male, 1 female, CCLI); ibid, VII-2000 (1 male, CCLI); ibid, VI-1993 (4 males, CCLI); ibid, 20-V-1995, M. Sat (3 males, 1 female, CCLI); ibid, 28-30-V-1995, C.-L. Li (3 males, 1 females, CCLI); ibid, 1-7-V-1996, Y. Arita (1 female, CCLI); Lam Dong: Mt. Braian, E. 45km Bao Loc, V-2005 (1 male, CCLI); Cao Bang: 5-VI1996, Itoh (2 females, CCLI). LAOS. Xamneua, Mt. Ph. Phan camp, ca. 1790m., 16-20-V-2004, C.-F. Lee (3 males, CCLI); ibid, 28-IV-2-V-2002, M. Satô (1 male, 1 female, CCLI); ibid, VI-2006 (1 male, CCLI); Houaphan: Ban Saleui, 1800m., 13-31-V-2004 (2 males, CCLI).

Distribution. Eastern and southern China and Hainan Island; northern Vietnam; northeastern Laos (new country record) (Fig. 19).

Remarks. This species is the only representative of the genus in the majority of mainland China. The old specimens that are deposited in the European museums indicate that they were likely active and common in the plains of central and northern China (Pekin, presently known as Beijing is probably the northernmost record of the species). However, this is not the case in southern China where their habitats are in montane areas similar to those of their other relatives in the genus. It has been observed that the body size of the specimens collected from the plains of northern China is generally smaller than those from southeastern localities. This morphometric trait was only detected with a larger number of specimens.

The populations of the species in northern Vietnam and Hainan Island have the similar habitat requirements in elevation to those in southeastern China. In addition to the varying color form of the body illustrated in Figs. 13-16, there is another overall black form from Hainan Island that differs from the dark green form of the Trichius miyashitai holotype. In fact, both color forms have been observed within populations of $E$. bowringii from Hainan Island. With the examination of specimens from Hainan Island, the black form of $E$. bowringii is greatly dominant in number of individuals over those that are an overall green color. Nevertheless, all of them are varied in the shape of the paramere while being consistent in the structure of the internal sac armatures. Therefore, we propose herein to place T. miyashitai a junior synonym of E. bowringii. 


\section{Epitrichius lagopus (Fairmaire)}

Trichius lagopus Fairemaire, 1897: 166 (Type locality: Amami-shima island, Japan. Type in NMNH); Schenkling 1922: 32 (catalog); Miwa \& Chûjô 1939: 30 (catalog); Krikken 1972: 492 (key, diagnosis, lectotype designated).

Trichius ferriei Pouillaude, 1913: 125; Krikken 1972: 488 (comment and placed in synonym)

Epitrichius lagopus, Ishida \& Fujioka 1988: 59 (catalog, generic combination); Fujioka 2001: 127 (catalog); Smetana 2006: 308 (catalog)

Specimens examined. JAPAN. Amami-Oshima: Hatsuno, 9-10-VII-1962, N. Obayashi (2 females, CCLI); ibid, 27-VI-1961 (1 male, CCLI); Naze, 6-VII-2002 (1 male, 1 female, CCLI).

Distribution. Amami-Oshima Island, southwestern Japan (Fig. 19).

Remarks. Epitrichius lagopus is a peculiar species within the genus with its distribution only on a small and remote island, Amami-Oshima, some 300 km southwest of Kyushu (Japan's southernmost main island). Morphologically, this species is similar to E. versutus with the setiferous surface of the head and pronotum as well the distinctly smaller size of the major hook on the internal sac. The triple transverse markings on each elytron are the most obvious characters that separate E. lagopus from all other species in the genus.

\section{Epitrichius versutus (Krikken), new combination}

Trichius versutus Krikken, 1972: 489 (Type locality: Mauson Mountains, Vietnam. Holotype in RMNH)

Type material examined. The male holotype, deposited in RMNH, is pinned with the following label: Tokin, Mtes Mauson/ Rolle, , Trichius/ fraterculus/ Moser/ coll. F. T. Valck Lucassen/ Trichius versutus nov. J. Krikken ms 1972, HOLOTYPE/ genitalia was dissected and glued to a paper point.

Specimens examined. VIETNAM: Tonkin, Montes Mauson, April, Mai 2-3000', H. Fruhstorfer (1 female, ISNB); Vin Phu: Tam Dao, 1100m., 12-V-2003, Mamoru Owada (1 female, NSMT); ibid, VI-VII1993 (1 male, Iwase coll.); ibid, IV-1994 (1 male, CCLI); Cao Bang, 5-VI-1996, Itoh (1 male, CCLI); ibid, 29-V-1995, Kume \& Itoh (1 female, CCLI).

Distribution. Northern Vietnam (Fig. 19).

Remarks. This species can be separated from species in the genus by the overall setiferous surface of the head and pronotum in both sexes, the setae along the base of the pronotum being denser and lighter in color, and the elytra with long semi-erect setae that is sparsely distributed around the scutellum and/or extends apically along the suture halfway down the elytra.

\section{Epitrichius shinshuingensis Li \& Yang, new species}

Figs. 1-7

Holotype male (Fig. 1). Body oval-elongate, length $22.2 \mathrm{~mm}$; width across humeri $9.5 \mathrm{~mm}$. Body overall metallic reddish cupreous except for elytra, elytral reddish brown with two dull yellow, transverse bands, margins diffused, hardly defined. Dorsum slightly iridescent under microscopic view. Canthi, inner side of protibia and anterior margin of metafemur with dull green reflections. Head: Surface glabrous, rugopunctures lengthwise developed and distributed along sides of gena and eyes, size of punctures becoming gradually smaller anteriorly. Anterior margin of clypeus strongly emarginated medially, bilobed tips protruding and moderately acute with very tiny and sparse punctures marginally. Vertex punctures unevenly distributed. Thorax: Pronotum widest at base, semihexagonal, basolateral angles strongly produced and flare outward, lateral margin well defined, weakly serrate (Fig. 2). Surface glabrous with setigerous punctures adjacent to anteriolateral angles; setae short, slender, whitish yellow; surface with sublateral medial concentration of fine setae 
observable only under microscope. Median longitudinal stripe a conspicuous, contiguous to impunctate area just in front of scutellum; punctures along sides of median stripe sparse, gradually denser laterally. Scutellum triangular, broader than long, rounded at apex, nearly impunctate only with a few weakly developed lateral punctures. Elytra: Shining and glabrous. Margins of elytral with transverse bands diffused, hardly defined. Disc nearly flat, surface with 3 impunctate carinae between suture and humerus, basal third obsolete, middle carinae raised; intervals with punctures scattered; elytral apex and lateral sides rugose. Abdomen: Propygidium clothed with fringe of long yellowish brown setae reaching basal margin. Pygidial width nearly 1.7 times length medially; rugopunctate in concentrical array when viewed caudally; paramedian tufts consisting of dense, long, yellowish brown setae, a pair of vestigial tubercles located between tufts; pygidial disc rarely with tiny setae. Anterior side with sparse, short setae; marginal ridge well developed, moderately truncate. Mesometasternal process strongly protruding with quadrate apex curved vertically when viewed laterally; variably tufted with golden setae in different arrays; metasternum with weakly impressed, median, longitudinal groove widening posteriorly, setose laterally; median metasternal suture well defined; elevations adjacent to median groove glabrous, impunctate at basal halves with row of long setae laterally. Discal center of metasternum with shorter setae; metepisternum finely and sparsely setose. Sternites 1-4 subequal in width, last sternite with subapex weakly sinuate. Sternites 1-4 with paired submedian tufts of long setae, impunctate centrally; sternite 5 with a semicircular tuft centrally; sternite 6 with sparse punctures unevenly distributed, more densely setose punctures tufted centrally, tuft distinctively smaller then on sternite 5 . Sternites 1-6 moderately rugopunctate on submedian to sublateral sides with densely setigenous areas from sternites $1-5$ and contiguous to transversely shorter setae of anterior margins of sternites $1-5$; lateral tips of sternites $2-4$ independently tufted with shorter setae. Legs: Protibia unidentate. Inner tips of procoxae, mesocoxae, and metacoxae densely tufted with long golden setae; anterior sides of profemur transversely ridged medially, weakened apically, setae distributed laterally on basal two-thirds. Mesofemora and metafemora having similar arrays of setae on posterior sides, ventral surface with widely separated rugae; profemora sparsely punctate; discs of all femora with only tiny, scattered setae. Anterior margins of protrochanters and mesotrochanters and posterior margins of mesotrochanters and metatronchanters tufted as on coxa and contiguous with setae of femora. Short setae on inner sides of mesotibiae and metatibiae sparsely distributed. Protarsi and mesotarsomere 5 weakly setose on ventral sides; apical notches of tarsomeres 1-4 tufted with deep-brown setae contiguous to ventrally parallel row of setae, length of setae approximately half of each tarsomere; metatarsomeres 25 ventrally covered with long yellowish brown setae, length of setae subequal to tarsomere; tarsomeres 2-4 fully setose on ventral side and tarsomere 5 with basal two-thirds setose; metatarsomere 1 with shorter deepbrown setae on venter and with longer whitish-yellow setae on apical notch; metatarsi 1.5 times longer than metatibiae; inner spurs of mesotibia and metatibia slightly longer than basal metatarsomeres; mesotarsomeres and metatarsomeres 1-4 subequal in length. Male genitalia: Paramere symmetrical, directed downwardly and basally, apex sharpened, inner margin emarginated medially (Fig. 3); ventral inter-paramere extensions with small, isolated sclerotized plate centrally (Fig. 4). Internal sac well developed, dorsum armed with two sclerotized hooks (Fig. 5), outer major hook distinctively larger than inner minor hook, major hook (Fig. 6) roughly trapezoidal in shape, apical tooth protruding upwardly, minor hook (Fig. 7) cork-shaped with upper and inner edges irregularly serrate.

Female. Unknown.

Diagnosis. This new species has parameres very similar in shape to those of Epitrichius fraterculus. However, E. shinshuingensis is distinguished from all other species in the genus by the following combination of characters: larger in body size, overall body including legs reddish cupreous with distinctive metallic reflections; pronotum widest at base; surface almost glabrous, punctures along sides of median stripe sparse; elytra shining, color reddish brown, margins of transverse bands diffused; abdominal sternites 1-4 with paired submedian tufts of long setae; protarsomere and mesotarsomere 5 weakly setose on ventral sides; inner spurs of mesotibia and metatibia slightly longer than basal metetarsomeres; apex of the parameres sharpened, inner 


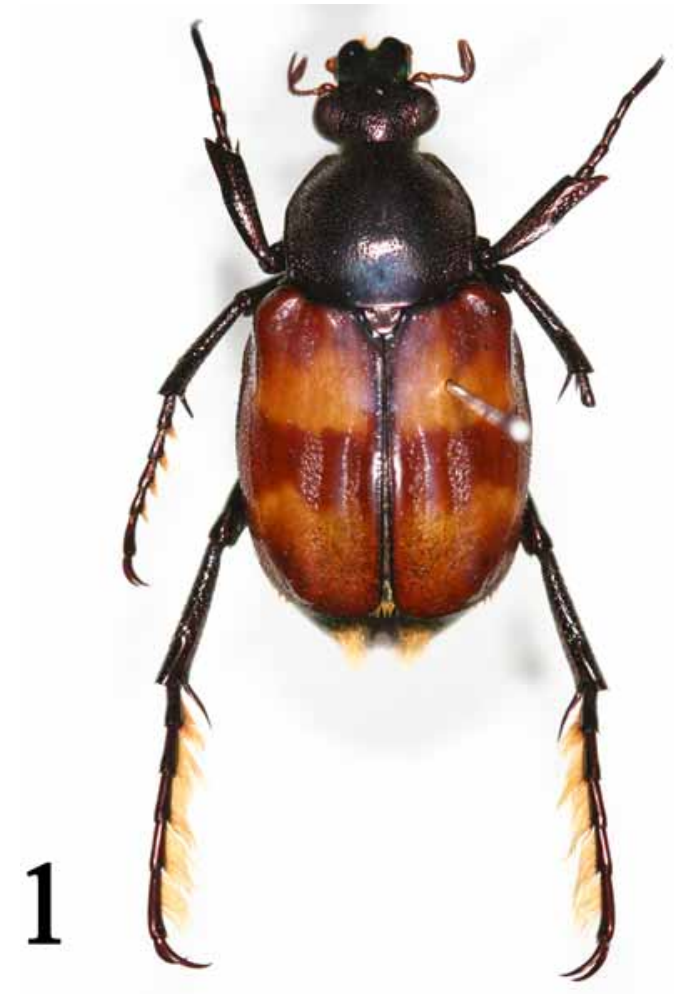

FIGURE 1. Dorsal habitus of Epitrichius shinshuingensis holotype.

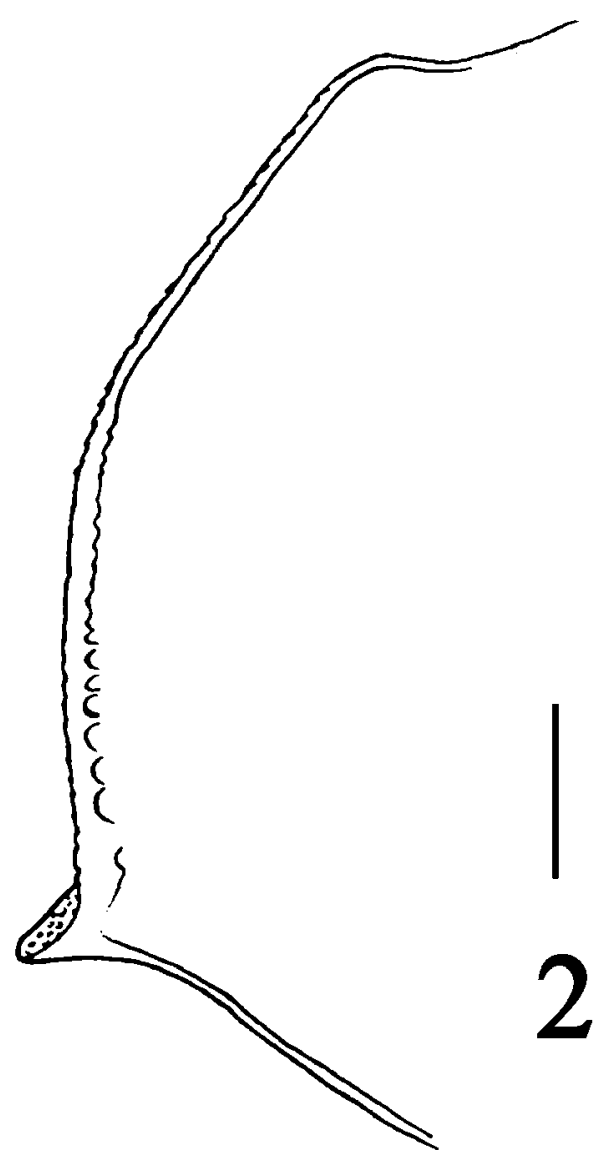

FIGURE 2. Lateral side of pronotum of Epitrichius shinshuingensis, scale bar $=2.0 \mathrm{~mm}$. 

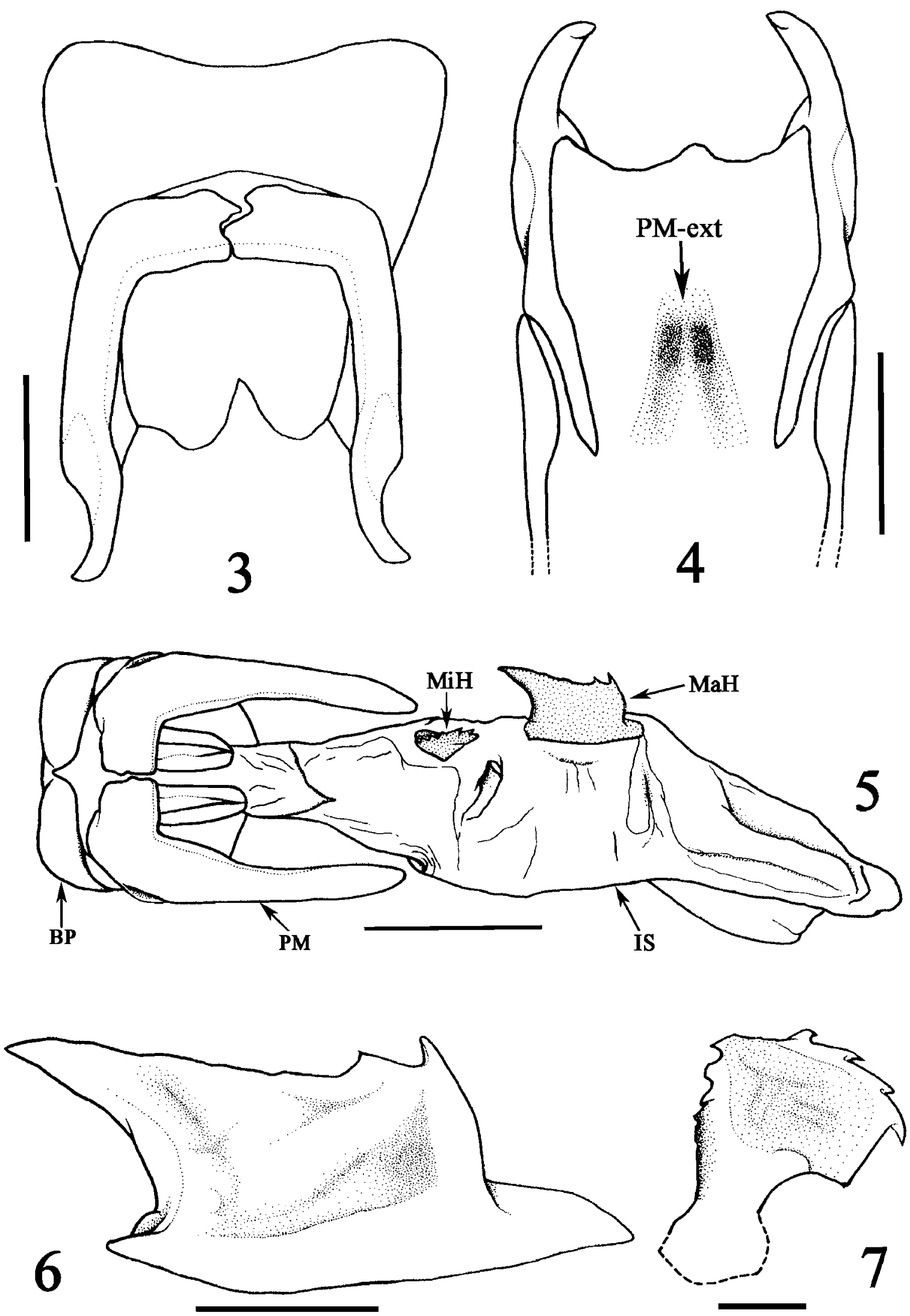

FIGURES 3-7. Male genitalia of Epitrichius shinshuingensis. 3. caudal view, scale bar $=1.0 \mathrm{~mm}$; 4. ventral view, scale $=1.0 \mathrm{~mm} ; 5$. parameres with internal sac everted, caudal view, scale bar $=2.0 \mathrm{~mm} ; 6$. major hook, scale bar $=0.5 \mathrm{~mm} ; 7$. minor hook, scale bar $=0.2 \mathrm{~mm}$. Abbreviations: $\mathrm{PM}$-ext $=$ paramere extensions; $\mathrm{BP}=$ basal piece; $\mathrm{PM}=$ parameres; $\mathrm{IS}=$ internal sac; $\mathrm{MiH}=$ minor hook; $\mathrm{MaH}=$ major hook. 

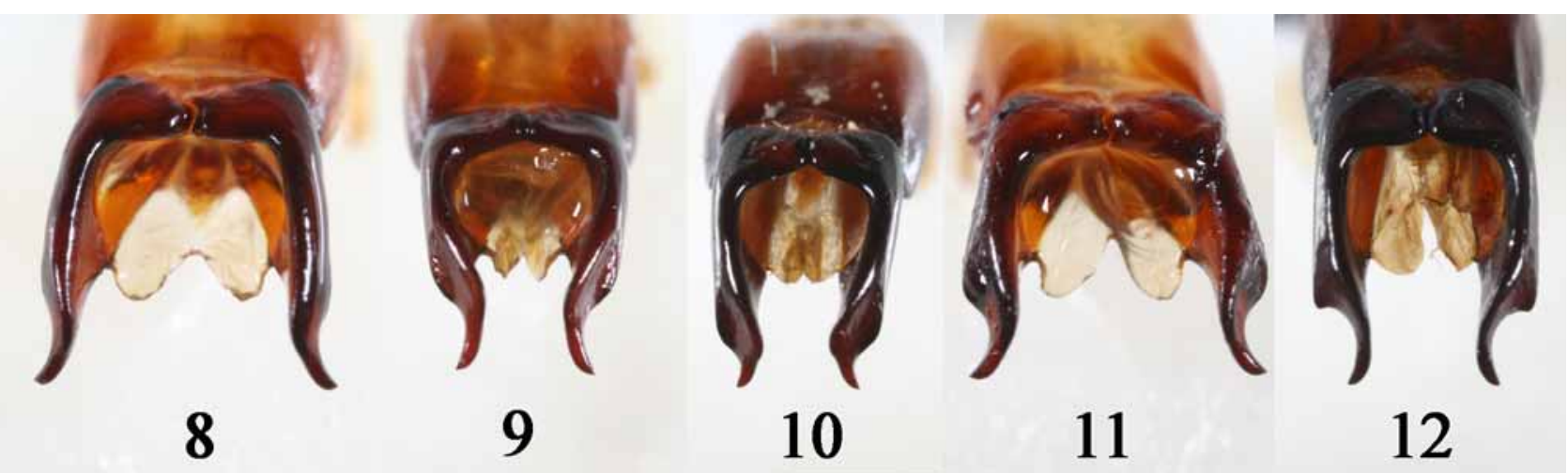

FIGURES 8-12. Variation in the shape of parameres of Epitrichius bowringii.

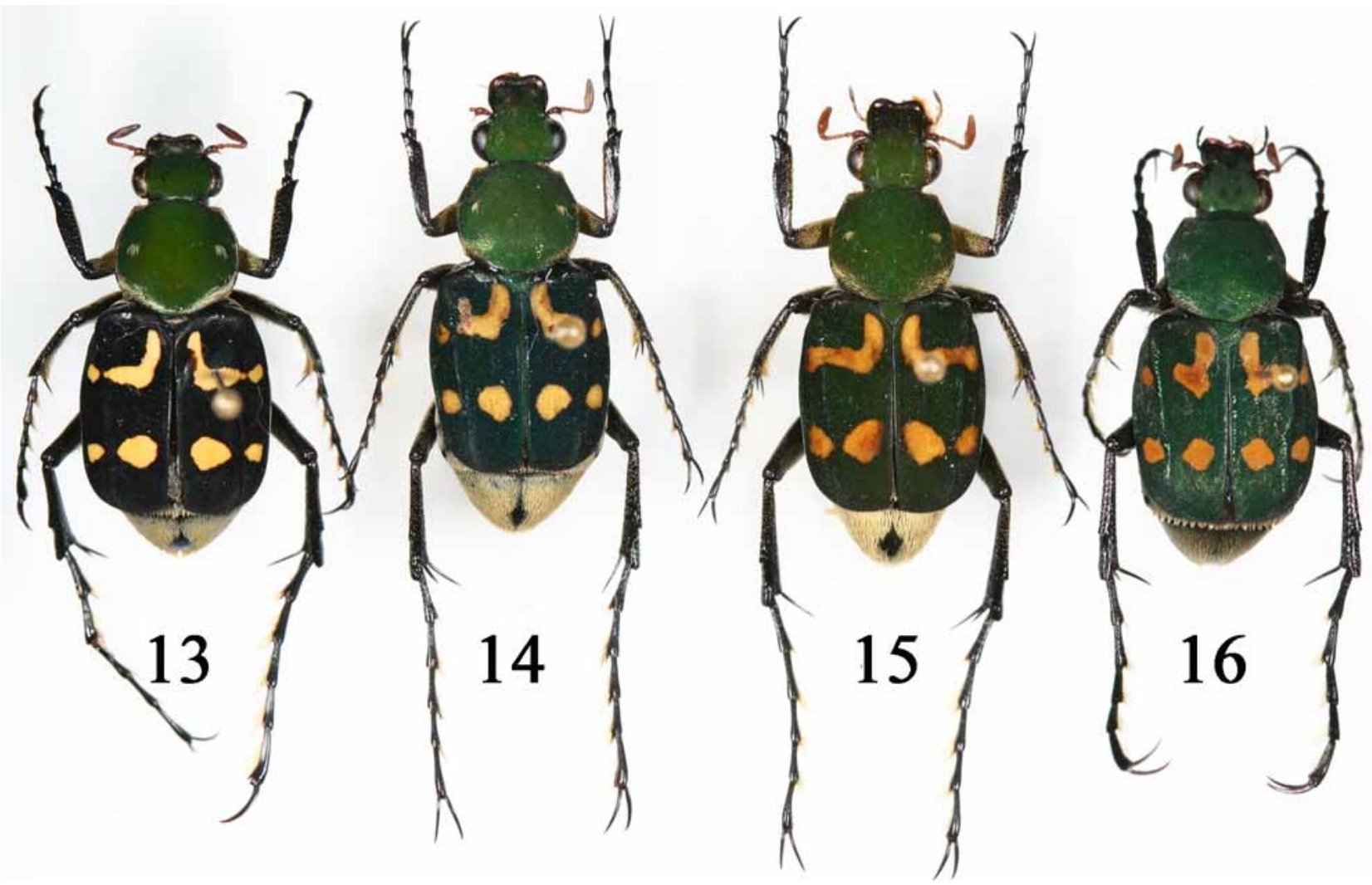

FIGURES 13-16. Variations in body color in Epitrichius bowringii 13. black elytra, (Houaphan, Laos); 14. dull green elytra, (Gwongxi, China); 15. (Gwongxi, China); 16. overall green, (Jiangxi, China).

side of parameres slightly swollen basal one-thirds; major hook of internal sac trapezoid and distinctively larger than minor hook.

Variation in the type series is slight. The body size of the single paratype is smaller with its length 19.6 $\mathrm{mm}$ and width $8.7 \mathrm{~mm}$. Also, the shape of the elytral transverse bands is less diffused and shorter than the holotype.

Type material. The male holotype is pinned and with the following information on the label: TAIWAN: Ping Tong Co., $21^{\text {st }} \mathrm{km}$., Da Haim logging road, alt. ca 1500m., 17/VIII/ 2004, visiting flowers of Elaceocarpus sylvestris, collr. K.-S. Hsu. The paratype male: same collecting locality as the holotype with different date and collector as on August 10, 2004, by L.-C. Shih. The holotype is deposited at the National Museum of Natural Science, Taichung, Taiwan and the paratype is deposited at the Department of Entomology, National Taiwan University, Taipei, Taiwan.

Distribution. Southern Taiwan (Fig. 19). 

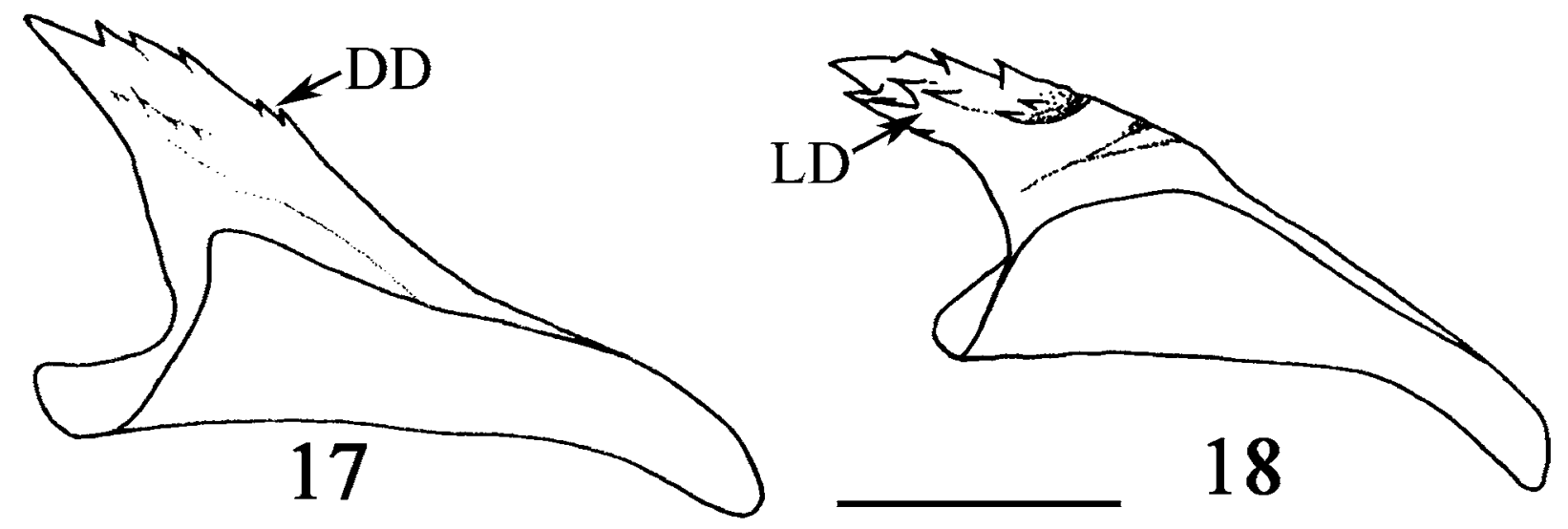

FIGURES 17-18. Major hooks of the internal sac. 17. Epitrichius bowringii; 18. Epitrichius cupreipes. Scale bar $=0.5$ $\mathrm{mm}$. Abbreviations: $\mathrm{DD}=$ dorsal denticle; $\mathrm{LD}=$ lateral denticle.

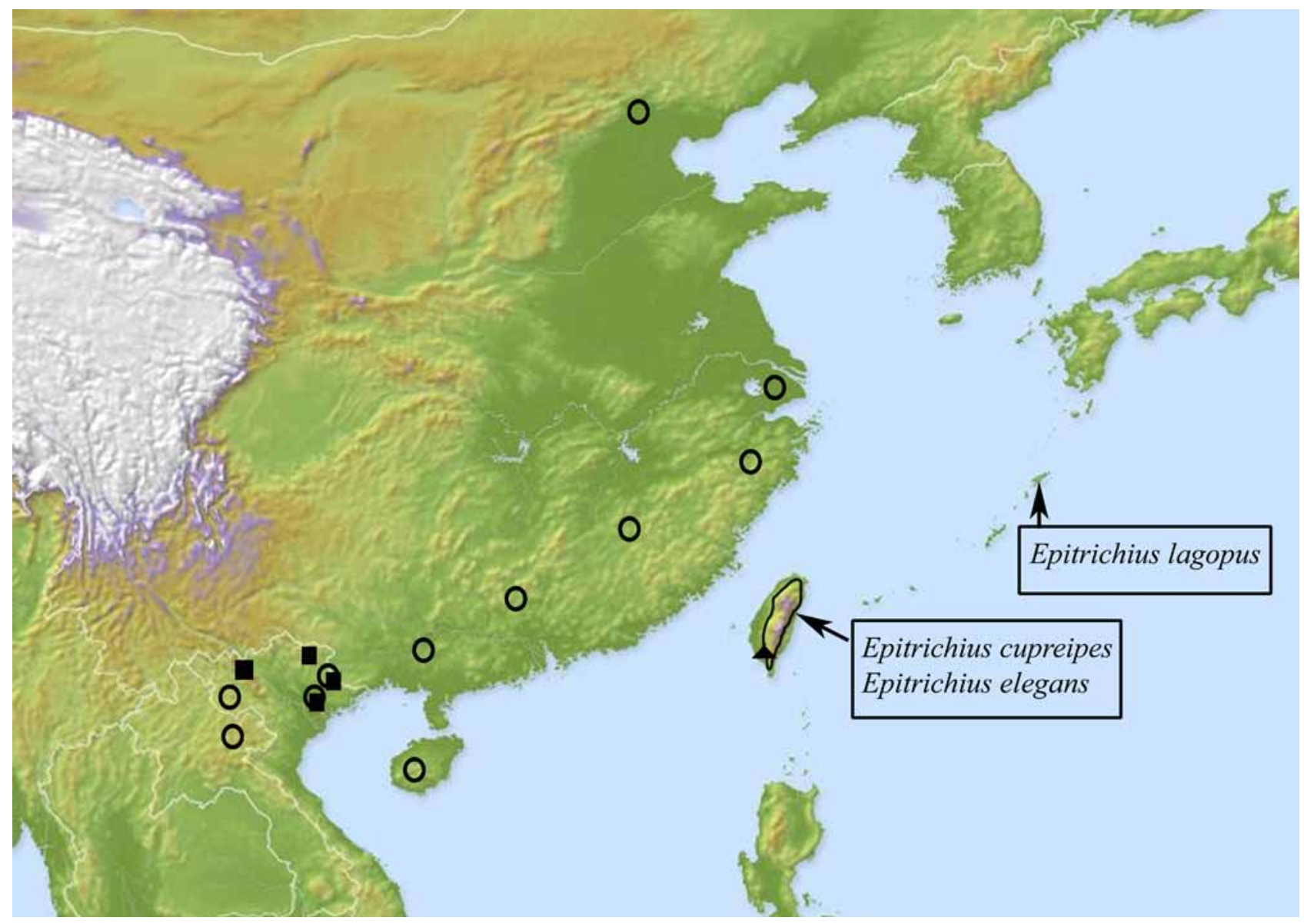

FIGURE 19. Geographical distribution of the Epitrichius species: Epitrichius bowringii (open circle), Epitrichius fraterculus and Epitrichius versutus (black square) and Epitrichius shinshuigensis (black triangle).

Etymology. The specific name refers to the old name of the collecting site, Shinshuigen, which is famous since the early 1910's for being the type locality of several vascular plants endemic to southern Taiwan.

Remarks. Based on collecting efforts over the past three years, adults of this species appear only for a very short period of time, which makes them very difficult to find. The two type specimens of this new species were collected separately from the flowers of Elaceocarpus sylvestris (Elaeocarpaceae) and Prunus phaeo- 
sticta (Rosaceae), two common and non-endemic trees in the broadleaved evergreen forests at low and middle elevations in Taiwan. The occurrence of E. shinshuingensis is seemingly restricted to the southern montane areas of Taiwan which distribution pattern is uncommon for scarab beetles in Taiwan.

\section{Epitrichius fraterculus (Moser), new combination \& new status}

Trichius fraterculus Moser, 1902: 533 (description); Schenkling 1922: 32 (catalog); Paulian 1961: 16 (key)

Trichius fraterculus fraterculus: Krikken 1972: 488 (new status, notes and distribution)

Trichius fraterculus duporti Bourgoin: Krikken, 1972: 489 (new status, notes and distribution). New synonym.

Specimens examined. VIETNAM. Tonkin, Montes Manson (presently Mauson Mountains, northern Vietnam), April, Mai, 2-3000', H. Fruhstorfer (1 male, Mus. Hauschild, ZMUC); ibid (1 male, coll. Janson-Valck Lucassen, RMNH); Vin Phu: Tam Dao, 28-30-V-1995 (1 male, CCLI); ibid, 20-V-1995, M. Sat (1 female, CCLI); ibid, IV-1994 (2 males, 1 female, CCLI); ibid, 900-950m., 14-18-V-1999, S. Nomura (1 male, 1 female, NSMT).

Distribution. Northern Vietnam (Fig. 19).

Remarks. Krikken (1972) divided E. fraterculus into two subspecies by considering the subspecies, E. $f$. duporti, with metallic luster on head and pronotum was found south of the Red River and compared it with its nominate subspecies without metallic luster which was north of the Red River. However, we have received a series of specimens with metallic luster which were recently collected from Tam Dao, a well-known place located north of the Red River in the province of Vinh Phu, Vietnam. Based on this it can be said that the Red River does not constitute a natural barrier to geographically isolate either subspecies. Additionally, the genital characters of the parameres and the internal sac armatures are identical to each male specimen examined. Accordingly, the individuals possess cupreous or copper green luster on both the head and the pronotum should be considered intraspecific variation and the subspecies $E$. f. duporti should be treated as a junior synonym of E. fraterculus.

\section{Acknowledgments}

We would like to thank the curators of the collections listed in this study for the loan of specimens. Li-Cheng Shih (Kaoshiung, Taiwan) provided us one of the type specimens of Epitrichius shinshuingensis and Kazuo Iwase (Bangkok, Thailand) for a specimen of Epitrichius versutus. Masayuki Fujioka (Tokyo, Japan) kindly supported us by making many Epitrichius specimens available to this study. The financial support of this research is mainly from the National Science Council, Taiwan (NSC 95-2313-B-002-080-MY3, 96-2811-B002-038). C.-L. Li was also supported in this work by the Foreign Researcher Fellowship from the Tropical Biosphere Research Center, University of the Ryukyus, Japan, coordinated by Professor Tokushiro Takaso.

\section{Literature cited}

Bourgoin, A. (1915) Description d'un Cetonia nouveau de Formose (Col. Scarabaeidae). Bulletin de la Socit Entomologique de France, 1915, 174-175.

Chandra, K. (1991) New genitalic characters for distinguishing Anomala dorsalis from Anomala fraterna. The Coleopterists Bulletin, 45(3), 292-294.

Crudgington, H.S. \& Siva-Jothy, M.T. (2000) Genital damage, kicking and early death. Nature, 407, 855-856.

D'Hotman, D. \& Scholtz, C.H. (1990a) Phylogenetic significance of the structure of the external male genitalia in the Scarabaeoidea (Coleoptera). Entomology Memoir, 77, 1-51. 
D'Hotman, D. \& Scholtz, C.H. (1990b) Comparative morphology of the male genitalia of derived groups of Scarabaeoidea (Coleoptera). Elytron, 4, 3-39.

Eberhard, W.G. (1985) Sexual Selection and Animal Genitalia. Harvard University Press, Cambridge, 256 pp.

Fairmaire, L. (1897) Descriptions de deux Coloptres nouveaux du Japon. Bulletin de la Socit Entomologique de France, 1897, 166-167.

Fujioka, M. (2001) A list of Japanese lamellicornia. Kogane Supplement, 1, 1-293.

Haubruge, E., Arnaud, L., Mignon, J. \& Gage, M.J.G. (1999) Fertilization by proxy: rival sperm removal and translocation in a beetle. Proceedings of the Royal Society of London. Series B, Biological Sciences, 266, 1183-1187.

House, C.M. \& Simmons, L.W. (2003) Genital morphology and fertilization success in the dung beetle Onthophagus taurus: an example of sexually selected male genitalia. Proceedings of the Royal Society of London. Series B, Biological Sciences, 270, 447-455.

Howden, H.F. (1994) A new Mexican Apeltastes Howden and notes on Guatemalan Paragnorimus Becker (Scarabaeidae: Trichiinae). The Coleopterists Bulletin, 48(4), 349-353.

Isida, M. \& Fujioka, M. (1988) A list of lamellicornia in Japan (1 $1^{\text {st }}$ ed. Supplement). Lamellicornia Supplement, 2 , 1-62.

Kano, T. (1931) Some new or unrecorded cetoniid-beetles from Formosa. Annotationes Zoologicae Japonenses, 17, 127134.

Krajcik, M. (2006) A new Trichius Fabricius from Hainan Island (Coleoptera, Scarabaeidae, Trichiinae). Animma.X, 14, 24-27.

Krikken, J. (1972) Species of the east Asian bifasciatus group in the genus Trichius Fabricius (Coleoptera, Cetoniidae). Zoologische Mededelingen, 47 (40), 481-501.

Krikken, J. (1984) A new key to the suprageneric taxa in the beetle family Cetoniidae, with annotated lists of the known genera. Zoologische Verhandelingen, 210, 1-75.

Ma, W.-z. (1995) Economic insect fauna of China, Fasc. 46, Coleoptera: Cetoniidae, Trichiidae and Valgidae. Science Press, Beijing, 210 pp.

Miwa, Y. (1931) A systematic catalogue of Formosan Coleoptera. Report of the Department of Agriculture of the Government Research Institute, 55, 1-359.

Miwa, Y. \& Chûjô, M. (1939) Scarabaeidae. Catalogus Coleopterorum Japonicorum, Pars 5. Noda-Syobo, Taihoku, 94 pp.

Moser, J. (1902) Neue Cetoniden-Arten aus Tokin, gesammelt von H. Fruhstorfer. Berliner Entomologische Zeitschrift, 46(1901), 525-538.

Niijima Y. \& Kinoshita, E. (1923) Die Untersuchungen ber japanische Melolonthiden II. (Melolonthiden Japans und ihre Verbreitung). Research Bulletins of the College Experiment Forest, College of Agriculture, Hokkaido Imperial University, 2, 1-253.

Paulian, R. (1961) Coloptres Scarabides de l'Indochine, II (Rutlines et Ctonines). Annales de la Socit Entomologique de France, 130, 1-47.

Pouillaude, I. (1913) Descriptions de deux espces nouvelles appartenant au genere Trichius Fabr. (Col. Trichides). Insecta, 3, 125-128.

Redtenbacher, L. (1867) Reise der sterreichischen Fregatte Novara um die Erde in den Jahren 1857, 1858,1859 unter den Befehlen des Commodore B. von Wllerstorf-Urbair. Zoologischer Theil. Zweiter Band: Coleopteren (Abth. I A, 1). Kaiserlich-Knigliche Hof- und Staatsdruckerei, Wien, iv+249 pp.

Schenkling, S. (1922) Scarabaeidae; Trichiinae, Valginae. Coleopterorum Catalogus, 75, 1-58.

Skelley, P. E. (1993) A method of genitalia preparation and dry preservation for Coleoptera. Proceedings of the Entomological Society of Washington, 95(2), 131-138.

Smetana, A. (2006) Scarabaeidae: Cetoniinae, pp. 283-313. In Löbl, I. \& Smetana A. (eds.). Catalogue of Palaearcic Coleoptera, volume 3. Apollo Books, Stenstrupt, 690 pp.

Tagawa, H. (1941) On the (Coleoptera, Scarabaeidae) subfam. Trichiinae of Japan. Transactions of the Kyushu Entomological Society, 3(1), 9-23.

Thomson, J. (1857) Description de trente-trois espces de Coloptres. Archives d'Entomologie, 1, 109-127. 